\title{
In Silico Prediction of Heliannuol A, B, C, D, and E Compounds on Estrogen Receptor $\beta$ Agonists
}

\author{
Roihatul Mutiah, Alif Firman Firdausy, Yen Yen Ari Indrawijaya, Hibbatullah* \\ Department of Pharmacy, Faculty of Medical and Health Sciences, Maulana Malik Ibrahim State Islamic \\ University of Malang, Indonesia
}

\begin{abstract}
Heliannuols has a benzoxepine ring that produces anticancer activity by the inhibition mechanism of phosphoinositide 3 kinases (PI3K). Heliannuols are a compound that can be found in the leaves of sunflower (Helianthus annuus L.). The purpose of this study is to predict interactions, toxicity, physicochemical, and pharmacokinetics of Heliannuol A, B, C, D, and $\mathrm{E}$ based in silico as candidate anticancer drugs. Estrogen receptor beta (ERB) is a new potential therapy for glioma with an antiproliferative effect. Ligands agonist ERB have the potential activity to inhibit the proliferation of glioma cells and the discovery of this ligand has opened new therapy through the ERB to prolong survival in cancer patients. Prediction of physicochemical properties based on Lipinski rules and penetrate in the blood-brain barrier. Receptor validation shows that $2 \operatorname{IOG}(\mathrm{A})$ has a smaller RMSD value than $210 G(B)$, receptor validation is valid if the RMSD value less than 2 . The result of molecular docking shows that Heliannuols comply with Lipinski rules and have low toxicity. Heliannuols also have a similar amino acid with comparison drug (Erteberel), but the rerank score of Erteberel still lower than Heliannuols.
\end{abstract}

Keywords: Helianthus annuus, Heliannuols, estrogen receptor B (ERB), in silico, toxicity.

\section{INTRODUCTION}

Sunflower plant (Helianthus annuus L.) has many chemical compounds, especially in the leaves of this plant containing monoterpene, diterpene, alkaloids, phenols, and lactone sesquiterpenes (Ceccarini, 2004). Heliannuols are one of the sesquiterpenes which has a benzoxepine ring and anticancer activity produced by the inhibition mechanism of phosphoinositide 3 kinases (PI3K) (Ghantous, et al., 2010; Hefron, et al., 2011; Kuntala, et al., 2017; Ren, et al., 2003). Heliannuol $\mathrm{A}, \mathrm{B}, \mathrm{C}, \mathrm{D}$, and $\mathrm{E}$ were obtained from sunflower leaves that had been immersed in water for $24 \mathrm{~h}$ and extracted with chloroform $(\mathrm{CH} 2 \mathrm{Cl} 2)$ then observed using HPLC with hexane and ethyl acetate solvents (Macias, et al., 1994; Macias, et al., 2000; Macias, et al., 2002). The new anticancer treatment therapy involves estrogen receptor beta-agonists (ER $\beta$ ) by the pathway of inhibiting cancer growth and anticancer therapy with estrogen receptors can reduce glioma cell proliferation (Sareddy, et al., 2012; Sareddy and Vadlamudi, 2015).

$E R \beta$ has quite a different function from $E R \alpha, E R \beta$ has antiproliferative action and

Submitted: September 29, 2020

Revised: February 9, 2021

Accepted: February 15, 2021

*Corresponding author: hibbatullah24@gmail.com 
overexpression of ER $\beta$ can reduce proliferation in cancer cells (Strom, et al., 2004; Hartman, et al., 2009; Nilsson, et al., 2011). This research focuses on estrogen receptor beta agonists because it has the potential as an antitumor therapy agent by activating beta subtypes and preventing proliferative effects on cancer. Ligands that are included as estrogen receptor beta-agonists that have the potential activity to inhibit the proliferation of glioma cells are DPN (Diarylpropionitrile), MFF101, Liquiri-tigenin, and LY500307 (comparison drug (Erteberel)) (Sareddy, et al., 2012; Sareddy and Vadlamudi, 2015). Erteberel is one of the agonists ER $\beta$ that has high potential in reducing glioma cell proliferation and it can penetrate the blood-brain barrier (Sareddy, et $a l ., 2016)$. The discovery of a specific agonists ER $\beta$ provided naturally has opened the development of new therapies through the estrogen receptor beta to prolong survival in cancer patients (Sareddy and Vadlamudi, 2015).

Based on the research by Sareddy, et al. (2012) show that ER $\beta$ pathway activation is a potential therapeutic target for glioma because ER $\beta$ agonists are under clinical trials and are well tolerated with fewer side effects. The use of ER $\beta$ as a therapeutic agent can be extended to clinical use and is predicted to be a new class of drugs for treating glioma. Future studies examining the mechanism of ER $\beta$ in cancer progression will be useful for maximizing treatment using ER $\beta$ natural ligands (Sareddy and Vadlamudi, 2015). The purpose of this study was to determine the activity of Heliannuols on estrogen receptor beta and the lack of information on estrogen receptor betaagonists as therapeutic agents in cancer patients, encouraging researchers to compile this study.

\section{MATERIALS AND METHODS}

\section{Software}

This research uses Chem Bio Draw Ultra 12.0 application, Avogadro, pkCSM online tool, Protox II online tool (accessed on January 2020), and Molegro Virtual Docker 6 (Lisensi expires on: January 01, 2099).

\section{Target and Template Selection}

The target of this research is the estrogen receptor beta 2I0G from Protein Data Bank (https:// www.rcsb.org). The test compounds of this research are Heliannuol A, B, C, D, and E where the SMILES code from Chem Bio Draw 12.0 and the Erteberel SMILES code from PubChem.

\section{Prediction of Physicochemical, Pharmacokinetic, and Toxicity Properties}

Prediction of physicochemical properties using the pkCSM online tool and the Protox II online tool by entering the SMILES code of the compound. The prediction of physicochemical properties is based on Lipinski's rules and the ability of compounds to penetrate the brain barrier membrane. Lipinski's rules use to evaluate compounds that have pharmacological activity with predictable physical and chemical properties as drug candidates for humans. While the prediction of pharmacokinetic properties using the online pkCSM tool is based on the absorption, distribution, metabolism, and excretion parameters. Toxicity prediction using the pkCSM online tool and the Protox II online tool based on several parameters and toxicity classes according to the Globally Harmonized System (GHS).

\section{Molecular Docking}

Molecular docking using Molegro Virtual Docker 6.0 to know the interaction between the test compound and the receptor. 2D structures of Heliannuol A, B, C, D, and E were drawn using Chem Draw Ultra 12.0 and to know the SMILES code of the test compounds then 3D structures were made using Avogadro and energy minimization was performed. Validation of molecular docking ER $\beta$ (2I0G) using Molegro Virtual Docker 6.0 and a docking simulation process was also performed. Validation of molecular docking result is the Root 
Mean Square Deviation (RMSD), the docking simulation process can be run if the RMSD value was less than $2 \AA$. The parameters used in docking simulation include rerank score, bond distance, and type of interaction.

\section{RESULTS}

\section{Prediction of Physicochemical Properties and Toxicity}

Prediction of physicochemical properties using Lipinski rules of five with several parameters includes molecular weight, the partition coefficient of octanol/water $(\log \mathrm{P})$, Hydrogen Bond Donors (HBD), and Hydrogen Bond Acceptors (HBA). Topological Polar Surface Area (TPSA) also a parameter to determine compound can penetrate the brain barrier membrane (Kelder, et al., 1999). The physicochemical test was used to predict that the compound has good permeability, high absorption, and can penetrate the blood-brain barrier. The results of physicochemical properties, the ability of compounds to penetrate the brain barrier membrane, and toxicity are shown in Table 1.

The results of physicochemical prediction show that all compounds comply with Lipinski rules, it can be predicted that all compound easy to absorption and has good permeability. The result of TPSA showed that all compounds have a TPSA value of less than 80 , it can be predicted that all compounds could penetrate the brain barrier membrane (Hughes, 2008). Heliannuol A, B, and C are in toxicity class 4 with Lethal Dose $\left(\mathrm{LD}_{50}\right) 300-2000$ $\mathrm{mg} / \mathrm{kg}$. Heliannuol D and Erteberel are in toxicity class 5 with $\mathrm{LD}_{50} 2000-5000 \mathrm{mg} / \mathrm{kg}$. Heliannuol A, B, C, D, E, and Erteberel were predicted to be nontoxic in the AMES Mutagenic test, not toxic in the Hepatotoxicity test, and did not cause skin irritation in the Skin Sensitization test.

\section{Prediction of Pharmacokinetic Properties}

Prediction of pharmacokinetic properties is based on the prediction of absorption, distribution, metabolism, and excretion (ADME) using the

Table 1. Prediction of physicochemical and toxicity.

\begin{tabular}{|c|c|c|c|c|c|c|c|c|c|c|c|c|}
\hline \multirow[b]{2}{*}{ Compound } & \multicolumn{6}{|c|}{ Physicochemical Properties } & \multicolumn{5}{|c|}{ Toxicity } & \multirow{2}{*}{$\begin{array}{c}\text { Lipinsk } \\
\text { Rules of } \\
\text { Five }\end{array}$} \\
\hline & $M W^{*}$ & $\log P^{*}$ & HBA* & $H B D *$ & Torsion* & TPSA** & $\begin{array}{c}\text { AMES } \\
\text { Mutagenic* }\end{array}$ & Hepatotoxicity* & $\begin{array}{c}\text { Skin } \\
\text { Sensitization* }\end{array}$ & $L D_{50} * *$ & $\begin{array}{c}\text { Class of } \\
\text { Toxicity** }\end{array}$ & \\
\hline Heliannuol A & 250.338 & 3.11622 & 3 & 2 & 0 & 49.69 & No & No & No & 860 & 4 & Yes \\
\hline Heliannuol B & 248.322 & 2.8922 & 3 & 2 & I & 49.69 & No & No & No & 482 & 4 & Yes \\
\hline Heliannuol C & 248.322 & 2.89222 & 3 & 2 & I & 49.69 & No & No & No & 500 & 4 & Yes \\
\hline Heliannuol D & 250.338 & 3.1162 & 3 & 2 & I & 49.69 & No & No & No & 2148 & 5 & Yes \\
\hline Heliannuol $\mathrm{E}$ & 248.322 & 2.89222 & 3 & 2 & 2 & 49.69 & No & No & No & 500 & 4 & Yes \\
\hline Erteberel & 282.339 & 4.1152 & 3 & 2 & I & 49.69 & No & No & No & 5000 & 5 & Yes \\
\hline
\end{tabular}

Description: *pkCSM online tool; **Protox II online tool.

pkCSM online tool. The results of the prediction of pharmacokinetic properties are shown in Table 2.

The result from the prediction of pharmacokinetic properties shows ADME of the compound, in this research shows that all compound is predicted to have good intestinal absorption with the value is more than $80 \%$ (Chander, et al., 2017). According to the pkCSM online tool page website (http://biosig.uni-melb.edu.au/pkcsm/theory), the compound has a high skin permeability if the $\log$ value of $\mathrm{Kp}>-2.5 \mathrm{~cm} / \mathrm{h}$, and all compound are predicted have high skin permeability. Caco2 permeability is good if the Papp value $>0.90 \mathrm{~cm} / \mathrm{s}$ and all compounds are predicted to have good permeability. Heliannuol $\mathrm{C}$ and $\mathrm{E}$ do not include as Pgp substrates, then they are not predicted to be 
Table 2. Prediction of pharmacokinetic properties.

\begin{tabular}{|c|c|c|c|c|c|c|c|}
\hline \multirow{2}{*}{\multicolumn{2}{|c|}{ Prediction Category }} & \multicolumn{6}{|c|}{ Result } \\
\hline & & Heliannuol A & Heliannuol B & Heliannuol C & Heliannuol D & Heliannuol E & Erteberel \\
\hline \multirow{8}{*}{ 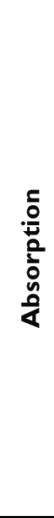 } & $\begin{array}{c}\text { Absorption in } \\
\text { intestine (\%) }\end{array}$ & 90.904 & 91.276 & $91.826^{* *}$ & 90.8 & $91.759^{+}$ & $93.474^{*}$ \\
\hline & $\begin{array}{l}\text { Skin Permeability } \\
\left(\text { Log } K_{p} \mathrm{~cm} / \mathrm{h}\right)\end{array}$ & -3.243 & -3.192 & $-3.285^{+}$ & -3.159 & $-3.35^{* *}$ & -2.751 \\
\hline & Caco-2 & & & & & & \\
\hline & Permeability(Log & $1.283^{*}$ & 1.3 & 1.242 & $1.312^{* *}$ & 1.248 & 1.248 \\
\hline & Ppap in $10^{-6} \mathrm{~cm} / \mathrm{s}$ ) & & & & & & \\
\hline & $\begin{array}{l}\text { P-glycoprotein } \\
\text { substrate }\end{array}$ & Yes & Yes & $\mathrm{No}^{++}$ & Yes & $\mathrm{No}^{++}$ & Yes \\
\hline & $\begin{array}{l}\text { P-glycoprotein I } \\
\text { inhibitor }\end{array}$ & No & No & No & No & No & No \\
\hline & $\begin{array}{l}\text { P-glycoprotein II } \\
\text { inhibitor }\end{array}$ & No & No & No & No & No & No \\
\hline \multirow{3}{*}{ 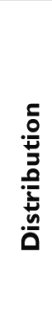 } & Vdss (Log L/kg) & 0.092 & 0.156 & 0.082 & $0.166^{* *}$ & $0.135^{+}$ & $0.378^{*}$ \\
\hline & $\begin{array}{c}\text { BBB Permeability } \\
\text { (Log BB) }\end{array}$ & $0.295^{* *}$ & -0.024 & $0.233^{+}$ & -0.023 & 0.221 & -0.062 \\
\hline & $\begin{array}{l}\text { CNS Permeability } \\
\text { (Log PS) }\end{array}$ & -2.769 & -2.793 & $-1.942^{* * *}$ & -2.787 & -2.042 & $-1.745^{*}$ \\
\hline \multirow{7}{*}{ 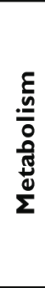 } & CYP2D6 substrate & No & No & No & No & No & No \\
\hline & CYP3A4 substrate & No & No & No & No & No & Yes $^{++}$ \\
\hline & CYPIA2 inhibitor & No & No & No & No & No & Yes $^{++}$ \\
\hline & CYP2CI9 inhibitor & No & No & No & No & No & Yes $^{++}$ \\
\hline & CYP2C9 inhibitor & No & No & No & No & No & Yes $^{++}$ \\
\hline & CYP2D6 inhibitor & No & No & No & No & No & No \\
\hline & CYP3A4 inhibitor & No & No & No & No & No & Yes $^{++}$ \\
\hline \multirow{2}{*}{ 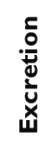 } & $\begin{array}{l}\text { Total Clearance } \\
\text { (Log } \mathrm{m} / / \mathrm{min} / \mathrm{kg} \text { ) }\end{array}$ & 0.947 & $1.009^{+}$ & $1.085^{* *}$ & 0.946 & $1.08^{* *}$ & 0.005 \\
\hline & $\begin{array}{l}\text { Renal OCT2 } \\
\text { substrate }\end{array}$ & No & No & No & No & No & No \\
\hline
\end{tabular}

Description: Vdss (Volume of Distribution at Steady State); BBB (Blood Brain Barrier); CNS (Central Nervous System); CYP2D6 (Cytochrome P2D); CYP3A4 (Cytochrome 3A4); CYP1A2 (Cytochrome 1A2); CYP2C19 (Cytochrome 2C19); CYP2C9 (Cytochrome 2C9); Renal OCT2 (Renal Organic Cation Transporter 2). *The highest value of comparative drugs; ${ }^{* *}$ The highest value of the first test compound; +The second highest value of the test compound; ++Different result from other.

removed from the target cell (Chakraborty and Ramakrishnan, 2016). Heliannuol A, B, C, D, E, and Erteberel are not included as Pgp I and II inhibitors, it predicts that the compound did not inhibit the work of the Pgp substrate (Robert and Jarry, 2003). The distribution volume of the compound is declared low if the Log Vdss value $<-0.15$ and high if the Log Vdss value $>0.45$, all compound has good distribution volume. Compounds with $\log \mathrm{BB}>0.3$ can penetrate the brain barrier membrane while compounds with $\log \mathrm{BB}<-1$ cannot be well distributed in the brain. Compounds with Log PS $>-2$ are considered to be able to penetrate CNS while $\log \mathrm{PS}<-3$ are considered unable to pene- 
Indonesian Journal of Cancer Chemoprevention, February 2021

ISSN: 2088-0197

e-ISSN: 2355-8989

iscce. III]CIC

Table 3. Validation of molecular docking.

\begin{tabular}{ccccc}
\hline \multirow{2}{*}{ Receptor } & \multicolumn{3}{c}{ RMSD (A) } & Average \pm SD (A) \\
\cline { 2 - 4 } & Replication I & Replication II & Replication III \\
\hline 2I0G (A) & 0.4429 & 0.7535 & 0.7794 & $0.6586 \pm 0.1872$ \\
210G (B) & 0.5947 & 0.8566 & 0.8296 & $0.7603 \pm 0.1440$ \\
\hline
\end{tabular}

trate CNS. All compound is predicted to penetrate the brain barrier and central nervous system. Heliannuol A, B, C, D, E are predicted not to be part of the CYP substrate or inhibitor then the compound is predicted to be metabolized without the help of cytochrome enzymes and does not inhibit the work of CYP 450. Whereas Erteberel is predicted to include CYP3A4 substrate and inhibitors of CYP1A2, CYP2C19, CYP2C9, CYP2C9, and CYP3A4. Heliannuol $\mathrm{C}$ is predicted to have a faster excretion process than other compounds because if the CLTOT value is higher then the excretion is faster (Hardjono, et al., 2018). Heliannuol A, B, C, D, E, and Erteberel are predicted to not include Organic Cation Transporter 2 (OCT2) substrate then the compound is predicted to be excreted without OCT2 substrate, OCT plays an important role in cationic drugs (Koepsell, 2015).

\section{Validation of Molecular Docking System}

RMSD is a parameter for receptor validation. The validation of molecular docking process is carried out by docking between the native ligand and the receptor, if the results obtained are less than 2 , it can be predicted that poses receptor with the native ligand is valid (Ruswanto, 2015). Validation of molecular docking result are shown in Table 3.

Validation of molecular docking result in table 3 show that the receptor has two ligands and the 2I0G(A) ligand has a smaller RMSD value than the $2 \mathrm{I} 0 \mathrm{G}(\mathrm{B})$ ligand.

\section{Docking Molecular and Interaction of Amino Acid}

The docking simulation process uses several parameters including the MolDock Score, Rerank Score, and $\mathrm{H}$ bond. The results of
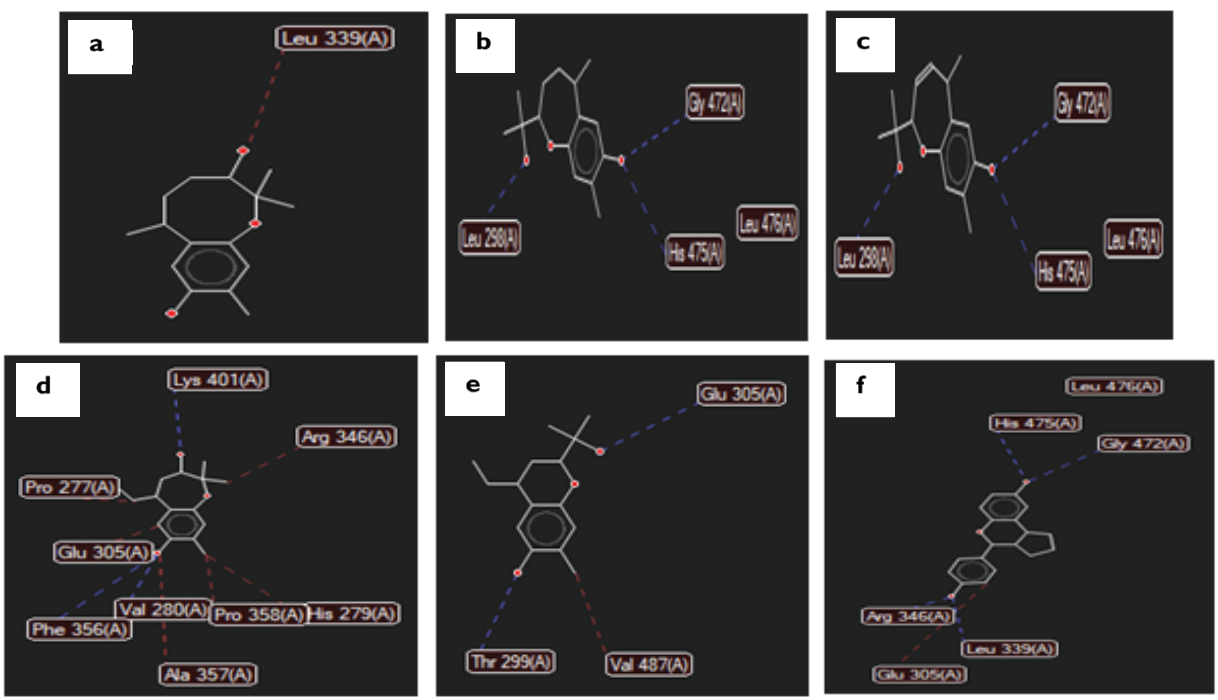

Figure 1. Interaction of amino acids between (a) Heliannuol A, (b) Heliannuol B, (c) Heliannuol C, (d) Heliannuol D, (e) Heliannuol E, (f) Erteberel on ERB with red color as steric bond and blue color as hydrogen bond. 
Table 4. Interaction of amino acid and rerank score.

\begin{tabular}{|c|c|c|c|}
\hline Compound & $\begin{array}{c}\text { Hidrogen Bond and } \\
\text { Distance }(\boldsymbol{A})\end{array}$ & $\begin{array}{c}\text { Steric Bond and } \\
\text { Distance }(A)\end{array}$ & $\begin{array}{c}\text { Rerank Score } \\
\text { (kcal/mol) }\end{array}$ \\
\hline \multirow[t]{2}{*}{ Heliannuol A } & - & Leu $339(3.09)^{*}$ & -69.988 \\
\hline & Gly 472 (2.6I) & & \\
\hline \multirow[t]{5}{*}{ Heliannuol B } & His $475(3.32)^{*}$ & - & -72.313 \\
\hline & Leu 298 (2.79) & & \\
\hline & & Arg $346(2.70)^{*}$ & \\
\hline & $\mid$ ve $40 \mid(300)$ & Pro 358 (2.89) & \\
\hline & Lys $401(3.00)$ & Pro 277 (2.79) & \\
\hline \multirow[t]{4}{*}{ Heliannuol C } & Val 280 (3.10) & His $279(2,99)$ & -78.532 \\
\hline & Phe $356(2.98)$ & Ala 357 (3.15) & \\
\hline & & Glu $305(2,93)^{*}$ & \\
\hline & Gly 472 (2.60) & & \\
\hline \multirow[t]{2}{*}{ Heliannuol D } & His $475(3.18)^{*}$ & - & -70.814 \\
\hline & Leu 298 (2.84) & & \\
\hline \multirow{4}{*}{ Heliannuol E } & Glu $305(2.60)^{*}$ & Val $487(3.12)$ & -80245 \\
\hline & Thr 299 (3.1I) & & \\
\hline & His $475(2.69)^{*}$ & & \\
\hline & Gly 472 (3.37) & & \\
\hline \multirow[t]{3}{*}{ Erteberel } & Leu 339 (3.10) & Glu 305 (2.99)* & -97.857 \\
\hline & $\operatorname{Arg} 346(2.82)^{*}$ & & \\
\hline & Glu 305 (3.29)* & & \\
\hline
\end{tabular}

Description: *Amino Acid of Heliannuols that same with Erteberel.

molecular docking are showed by the interaction of amino acids and rerank scores are shown in Figure 1 and Table 4.

In Figure 1 and Table 4 are show that Heliannuol A has a steric bond with the amino acid Leu 339, Heliannuol B has a hydrogen bond Gly 472, Leu 298, His 475, Heliannuol C has a hydrogen bond Lys 401, Val 280, Phe 356, and a steric bond Arg 346, Pro 358, Pro 277, His 279, Ala 357, Glu 305. Heliannuol D has hydrogen bonds Gly 472, His 475, Leu 298, Heliannuol E has hydrogen bonds Glu 305, Thr 299, and steric bonds Val 487. Whereas Erteberel has bonds hydrogen His 475, Gly 472, Leu 339, Arg 346, Glu 305 and steric bonds Glu 305.

\section{DISCUSSION}

The purpose of this research was to predict interactions, toxicity, and physicochemical properties of Heliannuol A, B, C, D, and E compounds using in silico study as anticancer. Prediction of physicochemical properties and toxicity is obtained by submitting the compound SMILES code into the pkCSM online tool and the ability to penetrate the brain barrier is obtained from the Protox II online tool. Heliannuol A, B, C, D, and E can be predicted easily absorbed and have good permeability because have a molecular weight less than $500, \log \mathrm{P}$ values are less than 5, HBD expressed by the number of $\mathrm{OH}$ groups and $\mathrm{NH}$ is less than 5 , and HBA which is expressed with some $\mathrm{O}$ and $\mathrm{N}$ atoms less than 10 (Lipinski, et al., 2001). All compounds have a TPSA value less than $80 \AA$, it can be predicted that the compound can penetrate the brain barrier membrane (Hughes, 2008). Heliannuol $\mathrm{A}, \mathrm{B}$, and $\mathrm{C}$ are in toxicity class 4 which means fatal if ingested with $\mathrm{LD}_{50} 300-2000 \mathrm{mg} / \mathrm{kg}$. Heliannuol D and Erteberel are in toxicity class 5 which means it might be dangerous if swallowed with $\mathrm{LD}_{50}$ 2000-5000 mg/kg (El-Din, et al., 2016). All compounds also were predicted to be non-toxic 
in the AMES Mutagenic test, not toxic in the liver, and did not cause skin irritation. Pharmacokinetic properties are used to determine the absorption, distribution, metabolism, and excretion of the test compound. The result of pharmacokinetic shows that Heliannuols have high absorption and can penetrate the brain barrier membrane where these compounds are expected as therapy in glioma patients. Besides, Heliannuol $\mathrm{C}$ and $\mathrm{E}$ are not included in the Pgp substrate then these compounds are predicted not to be removed from the cell and are expected to increase the therapeutic effect of the compound. This prediction is expected to be used as an additional prediction regarding the effects of the compound in the body before proceeding to the in vivo and in vitro tests.

This research shows that the receptor has two active sides that bind with the native ligand is 2I0G(A) and 2I0G(B). Ligand 2I0G(A) has a smaller RMSD value than $2 \mathrm{IOG}(\mathrm{B})$, it can be predicted that the active side of the receptor for the docking simulation is $2 \mathrm{I} 0 \mathrm{G}(\mathrm{A})$. The docking process can be performed if the receptor has RMSD value $\leq 2$ and the RMSD value from ligand $2 \mathrm{I} 0 \mathrm{G}(\mathrm{A})$ is $0.6586 \AA$. Prediction of molecular docking between Heliannuol $\mathrm{A}, \mathrm{B}, \mathrm{C}, \mathrm{D}$, and $\mathrm{E}$ with estrogen receptors $\beta(\mathrm{ER} \beta)$ show that Heliannuol $\mathrm{E}$ has the lowest energy with a rerank score of $-69.988 \mathrm{kcal} / \mathrm{mol}$ and predicted to have the most stable bond among other Heliannuols and predicted have the greatest activity. And if the result of the rerank score (the value of bond energy) is lower (more negative), the bond between the ligand and receptor is more stable, and the more stable bond between the ligand and receptor than the activity is high (Hardjono, 2012).

The result of amino acid interaction from this research includes hydrogen and steric bond. Heliannuols have the same several amino acids with an amino acid of the Erteberel by hydrogen bonds. Hydrogen bonds are non-covalent bonds that play a role in the biological activity produced (Muchtaridi, et al., 2018; Wijaya, et al., 2003). Erteberel bind to amino acid His 475, Glu 305, and Arg 346 with hydrogen bonds, a compound that binds with that amino acid can be classified as an ER $\beta$ agonist. Estrogen receptor beta agonist bind to amino acid Glu 305, Arg 346, His 475 (Meegan and Lloyd, 2003). Heliannuols have the same amino acid with an amino acid of the Erteberel by hydrogen bond, but Heliannuol A doesn't bind to amino acid His 475, Glu 305, and Arg 346. From the result of this study, it can be predicted that Heliannuol B, C, D, E have the same function with the Erteberel as an ER $\beta$ agonist. Prediction of physicochemical, pharmacokinetic, and toxicity from Heliannuols are predicted to have high absorption, good permeability, can penetrate the blood-brain barrier, and toxicity in classes 4 and 5. The docking result of Heliannuols is not good than the Erteberel because Erteberel still has the lowest rerank score than Heliannuols.

\section{CONCLUSION}

The conclusion from the research shows that Heliannuols have the same amino acid with the Erteberel, then can be predicted that Heliannuols have the same effect on estrogen receptor beta. When looked at its physicochemical, pharmacokinetics, and toxicity, Heliannuols has high absorption, can penetrate the brain barrier membrane, has good permeability and toxicity is in grades 4 and 5. However, the rerank score of Erteberel is still lower than Heliannuols. And for further research, it is recommended that Heliannuols be tested on other receptors to produce a lower rerank score of test compound than comparison compound.

\section{REFERENCES}

Ceccarini, 2004, Essential Oil Composition of Helianthus Annus L. Leaves and Heads of Two Cultivated Hybrids 'Carlos and Florom 350, Industrial Crops and Products.

Chakraborty, P. and Ramakrishnan, M., 2016, Role of P-Glycoprotein in Chemotherapeutic Drug Resistance and Mechanisms of Pump Deactivation to Overcome MDR in Cancer Cells A Critical Review, 
Frontiers in Biomedical Science, 1(2), 8.

Chander, S., Tang, C.R., Al-Maqtari, H.M., Jamalis, J., Penta, A., Hadda, T.B., Sirat, H.M., Zheng, Y.T. and Sankaranarayanan, M., 2017, Synthesis and Study of Anti-HIV-1 RT Activity of 5-Benzoyl-4Methyl-1,3, 4,5-Tetrahydro-2h-1,5-Benzodia-zepin-3-One Derivates, Bioorg Chem, 72, 74-79.

El-Din, H.M.A., Loutfy, S.A., Fathy, N., Elberry, M.H., Mayla, M.A., Kassem, S. and Naqvi, A., 2016, Molecular Docking Based Screening of Compounds Against VP40 Ebola Virus, Bioinformation, 12(3), 192-196.

Ghantous, A., Gali-Muhtasib, H., Vuorela, H., Saliba, N.A. and Darwiche, N., 2010, What Made Sesquiterpene Lactones Reach Cancer Clinical Trials?, Drug Discovery Today, 15(15-16), 668-678.

Hardjono, S., 2012, Modiikasi Struktur 1-(Benzoiloksi) Urea Dan Hubungan Kuantitatif Struktur Aktivitas Sitotoksiknya, Surabaya: Universitas Airlangga.

Hardjono, S., Siswandono, and Andayani, R., 2017, Evaluation of $\mathrm{N}$-Benzoylthiourea Derivatives as Possible Analgesic Agents by Predicting Their Hysicochemical and Pharmacokinetic Properties, Toxicity, and Analgesic Activity, Indonesian Journal of Biotechnology, 22(2), 76-85.

Hartman J., Edvardsson, K., Lindberg K., Zhao, C., Williams, C., Strom, A. and Gustafsson, J-A., 2009, Tumor Repressive Functions of Estrogen Receptor Beta in SW480 Colon Cancer Cells, Cancer Res, 69(15), 6100-6106.

Heffron, T.P., Wei, B., Olivero, A., Staben, S.T., Tsui, V. and Do, S., 2011, Rational Design of Phosphoinositide 3-Kinase A Inhibitors That Exhibit Selectivity Over the Phosphoinositide 3-Kinase B Isoform, J. Med. Chem, 54(22), 7815-7833.

Hughes, R.G., 2008, Patient Safety and Quality: An Evidence Base Handbook for Nurses, Rochville MD: Agency for Healthcare Research and Quality Publication.

Kelder, J., Grootenhuis, P.D., Bayada, D.M., Delbressine, L.P. and Ploemen, J.P., 1999, Polar
Molecular Surface as A Dominating Determinant for Oral Absorption and Brain Penetration of Drugs, Pharmaceutical Research, 16(10), 1514$1519 .$.

Koepsell, H., 2015, Role of Organic Cation Transporters in Drug-Drug Interaction, Expert Opin Drug Metab Toxicol, 11(10), 1619-1633.

Kuntala, N., Telu, J.R., Anireddy, J.S. and Pal, S., 2017, A Brief Overview on Chemistry and Biology of Benzoxepine, Letters in Drug Design and Discovery, 14(9), 1-13.

Lipinski, C.A., Lombardo, F., Dominy, B.W. and Feeney, P.J., 2001, Experimental and Computational Approaches to Estimate Solubility and Permeability in Drug Discovery and Development Settings, Advanced Drug Delivery Reviews, 46(1-3), 3-26.

Macias, F.A., Molinillo, J.M.G., Varela, R.M. and Torres, A., 1994, Structural Eludation and Chemistry of A Novel Family of Bioactive Sesquiterpenes: Heliannuols, J. Org. Chem, 59, 8261-66.

Macias, F.A., Varela, R.M., Torres, A. and Molinillo, J.M.G., 2000, Potential Allelopathic Activity of Natural Plant Heliannes: A Proposal of Absolute Configuration and Nomenclature, Journal of Chemical Ecology, 26(9), 2173-2186.

Macias, F.A., Torres, A., Galindo, J.L.G., Varela, R.M., Alvarez, J.A. and Molinillo, J.M.G., 2002, Bioactive Terpenoids from Sunflower Leaves CV. Peredovick, Phytochemistry, 61(6), 687-692.

Meegan, M.J. and Lloyd, D.G., 2003, Advances in The Science of Estrogen Receptor Modulation, Curr Med Chem, 10(3), 181-210.

Muchtaridi, Yanuar, A., Megantara, S. and Purnomo, H., 2018, Kimia Medisinal: Dasar Dasar Dalam Perancangan Obat Edisi Pertama, Jakarta: Prenada Media Group.

Nilsson S. and Gustafsson J.A., 2011, Estrogen Receptors: Therapies Targeted to Receptor Subtypes, Clin Pharmacol Ther, 89(1), 44-55.

Ren, W., Qiao Z., Wang H., Zhu L., and Zhang L., 2003, Flavonoids, Promising Anticancer Agents, 
Med Res Rev. 23(4), 519-534.

Robert, J. and Jarry, C., 2003, Multidrug Resistance Reversal Agents, Journal Med Chem., 46(23), 4805-4817.

Ruswanto, 2015, Molecular Docking Empat Turunan Isonicotinohydrazide Pada Mycobacterium Tuberculosis Enoyl-Acyl Carrier Protein Reductase (InhA), Jurnal Kesehatan Bakti Tunas Husada: Jurnal Ilmu-ilmu Keperawatan, Analis Kesehatan dan Farmasi, 13(1), 135-141.

Saini, S., and Sharma, S., 2011, Helianthus Annuus (Asteraceae): A Review, International Journal of Pharma Professional's Research, 2(4), 381386.

Sareddy, G.R., Nair, B.C., Gonugunta, V.K., Zhang, Q-g., Brenner, A., Brann, D.W., Tekmal, R.R. and Vadlamudi, R.K., 2012, Therapeutic Significance of Estrogen Receptor B Agonists in Gliomas, Molecular Cancer Therapeutics, 11(5), 1174-82.

Sareddy, G.R. and Vadlamudi, R.K., 2015, Cancer Therapy Using Natural Ligands That Target Estrogen Receptor Beta, Chinese Journal of
Natural Medicines, 13(11), 801-7.

Sareddy, G.R., Li, X., Liu, J., Viswanadhapalli, S., Garcia, L., Gruslova, A., Cavazos, D., et al., 2016, Selective Estrogen Receptor B Agonist LY500307 as a Novel Therapeutic Agent for Gliolastoma, Scientific Report, 6, 24185.

Siswandono, 2011, Studi Pemodelan Molekul Interaksi Beberapa Turunan Penisilin Dengan Reseptor DD-Transpeptidase Dari Streptomyces R61(1PWC), Airlangga Journal of Pharmacy, 9(2), 33-41.

Strom, A., Hartman, J., Foster, J.S., Kietz, S., Wimalasena, J. and Gustafsson, J-A., 2004, Estrogen Receptor Beta Inhibits 17Beta-Estradiol-Stimulated Proliferation of the Breast Cancer Cell Line T47D, Proc Natl Acad Sci USA, 101(6), 1566-1571.

Wijaya, K., Tahir, I. and Harnowo, 2003, Studi Mekanisme Migrasi Proton Ganda Pada Struktur Supermolekul Asam Asetat-Air dan Asam Asetat-Ammoniak dengan Metode Ab Initio, Indonesian Journal of Chemistry, 3(2), 102-110. 